\title{
Response surface design to study the influence of inoculum, particle size and inoculum to substrate ratio on the methane production from Ulex sp.
}

\author{
J.C. Costa, J.V. Oliveira, M.M. Alves* \\ CEB-Centre of Biological Engineering, University of Minho, Braga, Portugal
}

\section{A R T I C L E I N F O}

\section{Article history:}

Received 5 July 2015

Received in revised form

18 September 2015

Accepted 17 October 2015

Available online 10 November 2015

\section{Keywords:}

Anaerobic digestion

Biochemical methane potential

Factorial experimental design

Ulex europaeus

Inoculum to substrate ratio

\begin{abstract}
A B S T R A C T
Ulex europaeus is one of the world worst invaders vegetal species and its suitability for biogas production is significant. The effect of three factors affecting the Biochemical Methane Potential (BMP, expressed as volume of $\mathrm{CH}_{4}$ per mass of volatile solids of waste) and the biodegradability rate ( $k$, expressed in volume of $\mathrm{CH}_{4}$ per mass of VS and time) of $U$. europaeus was assessed by a Central Composite Face Centred Design. The BMP varied from $153 \mathrm{~L} \mathrm{~kg}^{-1}$ to $308 \mathrm{~L} \mathrm{~kg}^{-1}$. Inoculum to substrate ratio (ISR) and the type of inoculum had high influence on the final results. $k$ varied from $14 \mathrm{~L} \mathrm{~kg}^{-1} \mathrm{~d}^{-1}$ to $49 \mathrm{~L} \mathrm{~kg}^{-1} \mathrm{~d}^{-1}$. The conditions that simultaneously maximized the BMP and $k$ were an inoculum consisting in $55 \%(\mathrm{v})$ of granular sludge and $45 \%$ (v) of suspended sludge from a sludge digester, an ISR of $4 \mathrm{~g} \mathrm{~g}^{-1}$, and a particle size of $1.9 \mathrm{~mm}$. Considering the average biomass production in shrub land areas, the potential energy production from $U$. europaeus is estimated in $(36.9 \pm 19.3) \mathrm{GJ} \mathrm{ha}^{-1} \mathrm{yr}^{-1}$. For example, in Europe, a

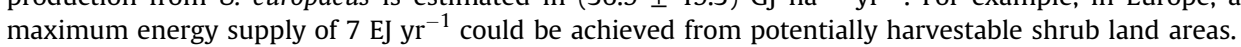

(c) 2015 Elsevier Ltd. All rights reserved.

\section{Introduction}

Exponential growth on energy demand and the limited reserves of fossil fuels, turns urgent to find alternative and diverse sources of renewable energy. Lignocellulosic waste from forests, mainly shrub, is widespread available at relatively low cost. Because it does not compete with food crops, it can contribute for the worldwide bioenergy scenario.

Ulex and Ulex europaeus is one of the 30 most invasive plant species in the world according to the World Conservation Union (IUCN) [1]. The species is considered as invasive in many parts of the world at different latitudes, including New Zealand, Australia, America (Chile, Colombia, California (USA), Oregon (USA), etc.) and tropical islands (Hawaii, Reunion) [2], though the centre of origin of Ulex is Portugal [3]. Shrubland areas, rich in biomass, occupy 1.9 million hectares in the Portuguese territory [4] and close to 1 million hectares in the region of Galicia (Spain) [5].

These areas are increasing rapidly due to the abandonment of agricultural land, which is rapidly becoming shrubland. Ulex sp. (also known as gorse, furze or whin) is an evergreen shrub in the

\footnotetext{
* Corresponding author.

E-mail address: madalena.alves@deb.uminho.pt (M.M. Alves).
}

family Fabaceae, which can go from $30 \mathrm{~cm}$ (Ulex minor) up to $3 \mathrm{~m}$ (U. europaeus) [6,7]. It creates an extreme fire hazard due to its oily, highly flammable foliage and seeds, and abundant dead material. It not only increases the risk of fire, but also produces a hotter fire than most weeds and the seeds are adapted to germinate after slight scorching by fire. The regular harvesting of shrubland areas in general and Ulex sp. in particular, might be valuable for diminishing the large greenhouse gas emissions associated to frequent wildfires in these regions [8], besides its suitability for energy production.

Biogas production through an anaerobic digestion process, using organic waste and plant biomass as feedstock, is one of the most economically cost-efficient renewable energy technologies [9]. The only attempt to explore Ulex sp. to produce biogas was reported by Eiroa et al. [10]. Only $34 \%$ of the theoretical methane production from Ulex sp. was achieved, suggesting that some process improvements needed to be applied. Several studies [11] have reported multiple pre-treatments to enhance the methane yields in the anaerobic digestion of lignocellulosic biomass. Although, these pre-treatments increased, significantly, the cost of process and compromise the economic viability of the scale-up process to an industrial scale [11]. Instead of pre-treatments, there are several parameters in a simple anaerobic digestion process that could be optimized. Biochemical methane potential (BMP) and methane 
production rate $(k)$ of a given substrate can be severely influenced by several parameters, including the type of inoculum and inoculum to substrate ratio (ISR) [12]. The particle size and corresponding surface area is another factor that deserves attention in the digestion of recalcitrant substrates [13].

This work aims at determine the influence of three variables, namely, inoculum type, substrate particle diameter $(d p)$ and ISR, on the BMP and $k$ of Ulex sp.. A response surface experimental design was used to statistically determine the most important variables and possible interactions. A central composite face centred design was chosen, where each factor (variable) was varied over 3 levels.

\section{Methods}

\subsection{Anaerobic biodegradability assays}

\subsubsection{Inoculum and substrate}

Biodegradability assays were performed using three different inocula: anaerobic suspended sludge (S), from a municipal wastewater treatment plant, anaerobic granular sludge (G), from a brewery industry, and a mixture (M) of the two previous inocula (50/50 TS). The inocula were characterised in terms of volatile solids (VS) and specific methanogenic activity, regarding the acetate (SAA) and hydrogen (SHMA) [14]. The specific cellulolytic activity (SCA) was determined as the initial methanogenic activity using avicel as substrate (Table 1 ).

Ulex sp. was collected in a shrubland in the North of Portugal (N41 ${ }^{\circ} 32^{\prime} 18.20^{\prime \prime}$ and $\mathrm{W}^{\circ} 21^{\prime} 21.96^{\prime \prime}$ ). It was dried at room temperature, for one week, and then crushed in an industrial mill into 3 different fractions: particles with diameters of $0.5 \mathrm{~mm}, 2.25 \mathrm{~mm}$, and $4 \mathrm{~mm}$. The samples were characterised in terms of total solids (TS) and VS, total and soluble chemical oxygen demand (COD and CODs, respectively), total kjeldahl nitrogen (TKN), ammonium $\left(\mathrm{N}-\mathrm{NH}_{4}^{+}\right)$, Klason lignin, xylan and glucan (Table 1$)$.

\subsubsection{Experimental procedure}

Biodegradability assays were performed according the directives defined by Angelidaki et al. [15]. Bottles were prepared by adding the substrate (Ulex sp.), inoculum (anaerobic sludge), and basal medium [15] containing $\mathrm{NaHCO}_{3}\left(5 \mathrm{~g} \mathrm{~L}^{-1}\right)$ to a final volume of $100 \mathrm{~mL} \mathrm{pH}$ of the medium was corrected for 7.0 to 7.2 with $\mathrm{NaOH}$ or $\mathrm{HCl}$ at $2 \mathrm{~mol} \mathrm{~L}^{-1}$. The vials were sealed and the headspace flushed

\section{Table 1}

Inocula and substrate characterisation. Specific methanogenic activity are expressed in volume of methane at STP conditions divided by amount of VS of inoculum and time $\left(\mathrm{mL} \mathrm{g}^{-1} \mathrm{~d}^{-1}\right)$. The parameters of substrate characterisation were determined per amount ( $\mathrm{g}$ ) of Ulex europaeus.

\begin{tabular}{lllc}
\hline & Suspended sludge & Granular sludge & Mixed sludge \\
\hline$T S /\left(\mathrm{g} \mathrm{L}^{-1}\right)$ & $75.0 \pm 9.4$ & $90.4 \pm 1.0$ & $76.5 \pm 3.1$ \\
$V S /\left(\mathrm{g} \mathrm{L}^{-1}\right)$ & $44.2 \pm 4.3$ & $83.2 \pm 1.0$ & $55.7 \pm 2.7$ \\
$S A A /\left(\mathrm{mL} \mathrm{g}^{-1} \mathrm{~d}^{-1}\right)$ & $<10$ & $130 \pm 15$ & $24 \pm 8$ \\
$S H M A /\left(\mathrm{mL} \mathrm{g}^{-1} \mathrm{~d}^{-1}\right)$ & $134 \pm 18$ & $357 \pm 14$ & $285 \pm 11$ \\
$S C A /\left(\mathrm{mL} \mathrm{g}^{-1} \mathrm{~d}^{-1}\right)$ & $25 \pm 1$ & $76 \pm 2$ & $71 \pm 9$ \\
& Ulex europaeus & & \\
\hline$T S /\left(\mathrm{g} \mathrm{g}^{-1}\right)$ & $0.68 \pm 0.02$ & & \\
$V S /\left(\mathrm{g} \mathrm{g}^{-1}\right)$ & $0.66 \pm 0.02$ & & \\
COD $/\left(\mathrm{g} \mathrm{g}^{-1}\right)$ & $0.94 \pm 0.05$ & & \\
TKN $/\left(\mathrm{g} \mathrm{g}^{-1}\right)$ & $0.0163 \pm 0.0002$ & & \\
$N-N H_{4}^{+} /\left(\mathrm{g} \mathrm{g}^{-1}\right)$ & $0.0080 \pm 0.0021$ & & \\
Lignin $/\left(\mathrm{g} \mathrm{g} \mathrm{g}^{-1}\right)$ & $0.170 \pm 0.001$ & & \\
Xylan $/\left(\mathrm{g} \mathrm{g}^{-1}\right)$ & $0.055 \pm 0.002$ & & \\
Glucan $/\left(\mathrm{g} \mathrm{g}^{-1}\right)$ & $0.175 \pm 0.020$ & & \\
\hline
\end{tabular}

SAA - specific acetoclastic activity.

SHMA - specific hydrogenotrophic methanogenic activity.

SCA - specific cellulolytic activity. with $\mathrm{N}_{2} / \mathrm{CO}_{2}(80 / 20 \mathrm{v})$. Before incubation, $\mathrm{Na}_{2} \mathrm{~S} \cdot 9 \mathrm{H}_{2} \mathrm{O}$ was added to a final concentration of $1 \mathrm{mmol} \mathrm{L}^{-1}$ in each vial. All batch tests were performed in triplicate and incubated at $37{ }^{\circ} \mathrm{C}$. Blank (only with inoculum) and control (with microcrystalline cellulose (average particle size $50 \mu \mathrm{m}$ )) assays were also performed.

Methane was monitored in the headspace by gas chromatography using a $500 \mu \mathrm{L}$ gas-tight syringe. Methane production was corrected for standard temperature and pressure (STP) conditions. $B M P$ was determined by Eq. (1) and is expressed in $\mathrm{L}$ of $\mathrm{CH}_{4}$ per $\mathrm{kg}$ of VS of substrate added to each vial $\left(\mathrm{L} \mathrm{kg}^{-1}\right)$. Where $\mathrm{COD}_{\mathrm{CH} 4}$ is the amount ( $\mathrm{g}$ ) of COD of substrate converted into $\mathrm{CH}_{4}$, also called cumulative methane production. The conversion to $\mathrm{CH}_{4}$ is made by the theoretical methane production of $1 \mathrm{~g}$ of $\mathrm{COD}\left(350 \mathrm{~L}^{\circ} \mathrm{CH}_{4}\right)$. The amount of VS of biomass (Ulex sp.) added to each vial is represented by $V S_{\text {substrate. }}$.

$B M P=\frac{C O D_{C H 4} \times 350}{V S_{\text {substrate }}}$

Biodegradability ( $B_{0}$, expressed in \%), was defined as the amount of methane produced during the assays in relation to the theoretical $B M P$ (i.e. $350 \mathrm{~L} \mathrm{~kg}^{-1}$ of COD) (Eq. (2)). Where, $C O D_{\text {added }}$ is the amount $(\mathrm{g})$ of COD of substrate added in the beginning of the assay, to each vial.

$B_{0}=\frac{C O D_{C H 4}}{C O D_{\text {added }}} \times 100$

Hydrolysis extent was evaluated considering the percentage of solubilisation $\left(P_{\text {Sol. }}\right.$, expressed in \%), which is the percentage of the initial COD added to the vials that was solubilised during the anaerobic biodegradability assay (Eq. (3)). The soluble COD measured in the beginning $\left(C O D_{s i}\right)$ and at the end $\left(C O D_{s f}\right)$ of each assay and the methane produced $\left(\mathrm{COD}_{\mathrm{CH} 4}\right)$ during the assay were used to calculate this parameter. All values of COD were expressed in $g$.

$P_{\text {Sol. }}=\frac{C O D_{s f}+C O D_{C H 4}-C O D_{s i}}{C O D_{\text {added }}} \times 100$

\subsection{Analytical methods}

For the characterisation, Ulex sp. samples were crushed, forming a powder with particle diameters $<0.5 \mathrm{~mm}$. TKN, TS, and VS were measured according to standard methods [16]. Total and soluble COD were determined using standard kits (Hach Lange, Düsseldorf, Germany). Ammonium ( $\left.\mathrm{NH}_{4}^{+}\right)$was determined by the Nessler method [16]. Klason lignin, xylan and glucan were analysed according to NREL protocols [17].

Volatile fatty acids (VFA) were determined by high-performance liquid chromatography (HPLC) (Jasco, Japan) equipped with a UV detector $(210 \mathrm{~nm})$ and a Chrompack column $(6.5 \mathrm{~mm} \times 30 \mathrm{~mm})$ at $60{ }^{\circ} \mathrm{C}$ and using sulfuric acid $\left(0.5 \mathrm{~mol} \mathrm{~L}^{-1}\right)$ as mobile phase at a flow rate of $0.6 \mathrm{~mL} \mathrm{~min}^{-1}$. Methane content in the biogas was analysed in a gas chromatograph (Chrompack 9000) equipped with a FID detector and a $2 \mathrm{~m} \times 1 / 8^{\prime \prime}$ Chromosorb 101 (80-120 mesh) column, using nitrogen as carrier gas $\left(30 \mathrm{~mL} \mathrm{~min}^{-1}\right)$; column, injector, and detector temperatures were $35^{\circ} \mathrm{C}, 110^{\circ} \mathrm{C}$, and $220^{\circ} \mathrm{C}$, respectively.

\subsection{Statistical analysis}

\subsubsection{Response surface design of experiments}

Experimental design allows studying the effects of more than one factor at two or more levels. It generally includes various combinations of different factor levels, which enables it to depict 
Table 2

Factors and respective levels in the experiments design of Central Composite Face Centred.

\begin{tabular}{|c|c|c|c|c|}
\hline Factor & Units & -1 & 0 & +1 \\
\hline A Inoculum & not applicable & Suspended & Mixed & Granular \\
\hline $\mathrm{B} d p$ & $\mathrm{~mm}$ & 0.5 & 2.25 & 4 \\
\hline C ISR & $\mathrm{g} \mathrm{g}^{-1}$ & 1 & 2.5 & 4 \\
\hline
\end{tabular}

the interactions among different factors and to deal with a large number of factors, compared with univariate design [18]. Central Composite Face Centred (CCFC) is a three-level factorial design, where the star points are at the centre of each face of the factorial space, so $\alpha= \pm 1$ [19].

The total number of assays required for three independent variables $(\mathrm{N})$ was calculated using Eq. (4). Where $f$ is the number of independent variables, therefore $\mathrm{N}=15$, given a total of 45 assays considering triplicates.

$N=2^{f}+2 f+1$

The values of the independent variables were normalized from -1 to +1 using Eq. (5) [20] to provide the comparison of the coefficients and visualization of the individual independent variables on the response. Where, $X_{i}$ is the coded (transformed variable), $y_{i}$ are the original (untransformed) values of the variables, and $y^{+}$and $y^{-}$are the upper and lower limit value of the variable.

$X_{i}=\frac{y_{i}-\frac{y^{+}+y^{-}}{2}}{\frac{y^{+}+y^{-}}{2}}$

The design matrix of the experiments and their statistical analysis were made by means of the software package DesignExpert $^{\mathbb{B}}$ (Stat-Ease, Inc., Minneapolis, USA). For response surface methodology, a second-order polynomial model (Eq. (6)) was used to describe the effects of the three factors (Table 2) on a response based on experimental results from CCFC. In Eq. (6), $Y_{i}$ is the response variable, $\beta_{0}$ is the constant, $\beta_{i}$ is the linear effect, $\beta_{i i}$ is the quadratic effect, $\beta_{i j}$ is the interactive effect and $X_{i}$ is the coded factor level.

$Y_{i}=\beta_{0}+\sum \beta_{i} X_{i}+\sum \beta_{i i} X_{i}^{2}+\sum \beta_{i j} X_{i} X_{j}$

The quality of the fit of the polynomial model equation was evaluated by the coefficient of determination $R^{2}$ and the statistical significance was evaluated by the Fisher's F-test for analysis of variance (ANOVA) with a $95 \%$ confidence level. The effect of each independent variable and also their interaction effects were determined.

\section{Results and discussion}

\subsection{Biochemical methane potential}

Ulex sp. has high COD concentration, a moisture content of $32 \%$, while $97 \%$ of the TS are VS (Table 1), suggesting it as a good biomass for anaerobic biodegradability. Around $10 \%$ are proteins while $17 \%$ are lignin, and glucan content reach $18 \%$ (Table 1 ). The high complex structure and heterogeneity are the major challenge for the anaerobic digestion of lignocellulosic biomass [21].

$B M P$ assays were performed according to the matrix in Table 3, to assess the influence of the inoculum type, $d p$ and ISR. The microcrystalline avicel (control) had methane yields of (93 \pm 2$) \%$, $(98 \pm 2) \%$ and $(96 \pm 4) \%$, respectively for suspended, mixed and granular sludge, demonstrating a good cellulolytic activity of all inocula. Fig. 1 shows the cumulative methane production $\left(\mathrm{COD}_{\mathrm{CH} 4}\right)$ during the anaerobic biodegradability assays using suspended sludge (Fig. 1a), mixed sludge (Fig. 1b) and granular sludge (Fig. 1c). $80 \%$ of the maximum methane produced was achieved after around 1 month of operation.

Table 3 shows the results obtained at the end of the assays. The best results were obtained in the assays $16-18\left((308 \pm 13) \mathrm{L} \mathrm{kg}^{-1}\right.$ with granular sludge, $\left.d p=0.5 \mathrm{~mm}, I S R=4 \mathrm{~g} \mathrm{~g}^{-1}\right)$ and $42-45$ $\left((308 \pm 1) \mathrm{L} \mathrm{kg}^{-1}\right.$ with mixed sludge, $d p=2.25 \mathrm{~mm}$, ISR $\left.=4 \mathrm{~g} \mathrm{~g}^{-1}\right)$. $B_{0}$ varied between $31 \%$ and $62 \%$, confirming that a significant portion of the available substrate is not being converted to methane and that all parameters tested had an important influence on the $B M P$ determination for the Ulex sp.. In this case is difficult to analyse the influence of each variable independently. Therefore, a statistical analysis was carried out to quantify which factors and respective

Table 3

Design matrix of the $2^{3}$ factorial experimental design and observed response factors (average of triplicates \pm standard deviation).

\begin{tabular}{|c|c|c|c|c|c|c|c|c|c|c|}
\hline \multirow[b]{3}{*}{ Test } & \multicolumn{3}{|c|}{ Independent variables matrix } & \multicolumn{2}{|c|}{ Response variables } & \multicolumn{5}{|c|}{ Final measurements } \\
\hline & \multirow{2}{*}{$\frac{X_{1}}{\text { Inoculum }^{a}}$} & \multirow{2}{*}{$\frac{X_{2}}{\frac{d p}{m m}}$} & \multirow{2}{*}{$\frac{X_{3}}{\frac{I S R}{\mathrm{~g} \mathrm{~g}^{-1}}}$} & \multirow{2}{*}{$\frac{Y_{1}}{\frac{B M P^{*}}{L \mathrm{~kg}^{-1}}}$} & \multirow{2}{*}{$\frac{Y_{2}}{\frac{k}{\mathrm{~L} \mathrm{~kg}^{-1} \mathrm{~d}^{-1}}}$} & \multirow[b]{2}{*}{$\frac{B_{0} *}{\%}$} & \multirow[b]{2}{*}{$\frac{P_{\text {Sol. }}}{\%}$} & \multirow[b]{2}{*}{$\frac{\mathrm{CODS}^{*}}{\mathrm{mg} \mathrm{L}^{-1}}$} & \multirow[b]{2}{*}{$\mathrm{pH}$} & \multirow[b]{2}{*}{$\frac{N-N_{4}^{+}}{\mathrm{mg} \mathrm{L}^{-1}}$} \\
\hline & & & & & & & & & & \\
\hline $1-3$ & $-1(S)$ & $-1(0.5)$ & $-1(1)$ & $154 \pm 9$ & $16.0 \pm 0.0$ & $31 \pm 2$ & $41 \pm 1$ & $325 \pm 28$ & $7.27 \pm 0.04$ & $532 \pm 5$ \\
\hline $4-6$ & $-1(\mathrm{~S})$ & $-1(0.5)$ & $+1(4)$ & $259 \pm 30$ & $37.5 \pm 2.1$ & $52 \pm 6$ & $64 \pm 4$ & $91 \pm 22$ & $7.29 \pm 0.03$ & $455 \pm 26$ \\
\hline $7-9$ & $-1(S)$ & $+1(4.0)$ & $-1(1)$ & $153 \pm 3$ & $14.6 \pm 0.4$ & $31 \pm 0$ & $42 \pm 1$ & $336 \pm 37$ & $7.24 \pm 0.01$ & $607 \pm 10$ \\
\hline $10-12$ & $-1(S)$ & $+1(4.0)$ & $+1(4)$ & $256 \pm 3$ & $34.2 \pm 0.6$ & $52 \pm 1$ & $60 \pm 2$ & $65 \pm 17$ & $7.30 \pm 0.01$ & $489 \pm 11$ \\
\hline $13-15$ & $+1(\mathrm{G})$ & $-1(0.5)$ & $-1(1)$ & $200 \pm 4$ & $21.3 \pm 1.3$ & $40 \pm 1$ & $58 \pm 1$ & $557 \pm 56$ & $7.27 \pm 0.04$ & $1069 \pm 27$ \\
\hline $16-18$ & $+1(\mathrm{G})$ & $-1(0.5)$ & $+1(4)$ & $308 \pm 13$ & $39.3 \pm 1.8$ & $62 \pm 3$ & $80 \pm 2$ & $137 \pm 31$ & $7.35 \pm 0.01$ & $895 \pm 112$ \\
\hline $19-21$ & $+1(G)$ & $+1(4.0)$ & $-1(1)$ & $176 \pm 9$ & $22.1 \pm 1.2$ & $36 \pm 2$ & $55 \pm 1$ & $601 \pm 29$ & $7.28 \pm 0.01$ & $1131 \pm 52$ \\
\hline $22-24$ & $+1(\mathrm{G})$ & $+1(4.0)$ & $+1(4)$ & $291 \pm 9$ & $37.1 \pm 3.5$ & $59 \pm 2$ & $73 \pm 4$ & $110 \pm 32$ & $7.36 \pm 0.01$ & $1014 \pm 20$ \\
\hline $25-27$ & $0(\mathrm{M})$ & $0(2.25)$ & $0(2.5)$ & $265 \pm 5$ & $35.7 \pm 0.8$ & $53 \pm 1$ & $66 \pm 1$ & $155 \pm 26$ & $7.34 \pm 0.01$ & $913 \pm 64$ \\
\hline $28-30$ & $-1(S)$ & $0(2.25)$ & $0(2.5)$ & $216 \pm 12$ & $26.5 \pm 1.4$ & $44 \pm 2$ & $50 \pm 2$ & $92 \pm 16$ & $7.24 \pm 0.02$ & $442 \pm 12$ \\
\hline $31-33$ & $+1(\mathrm{G})$ & $0(2.25)$ & $0(2.5)$ & $246 \pm 4$ & $32.5 \pm 0.8$ & $50 \pm 2$ & $61 \pm 0$ & $210 \pm 20$ & $7.21 \pm 0.01$ & $944 \pm 16$ \\
\hline $34-36$ & $0(\mathrm{M})$ & $-1(0.5)$ & $0(2.5)$ & $226 \pm 21$ & $34.5 \pm 0.3$ & $46 \pm 4$ & $56 \pm 5$ & $127 \pm 22$ & $7.33 \pm 0.02$ & $982 \pm 28$ \\
\hline $37-39$ & $0(\mathrm{M})$ & $+1(4.0)$ & $0(2.5)$ & $201 \pm 18$ & $32.9 \pm 1.1$ & $40 \pm 4$ & $51 \pm 4$ & $149 \pm 30$ & $7.40 \pm 0.16$ & $1026 \pm 30$ \\
\hline $40-42$ & $0(\mathrm{M})$ & $0(2.25)$ & $-1(1)$ & $188 \pm 14$ & $27.2 \pm 0.5$ & $38 \pm 3$ & $53 \pm 4$ & $458 \pm 51$ & $7.24 \pm 0.01$ & $1048 \pm 41$ \\
\hline $42-45$ & $0(\mathrm{M})$ & $0(2.25)$ & $+1(4)$ & $308 \pm 1$ & $48.0 \pm 1.2$ & $62 \pm 0$ & $70 \pm 3$ & $66 \pm 27$ & $7.26 \pm 0.01$ & $988 \pm 19$ \\
\hline
\end{tabular}

*the values obtained in the blanks were subtracted in the data presented in the table.

${ }^{a} \mathrm{G}-100 \%$ granular sludge; $\mathrm{S}-100 \%$ suspended sludge; $\mathrm{M}-$ Mixed sludge (50/50 TS of G/S). 

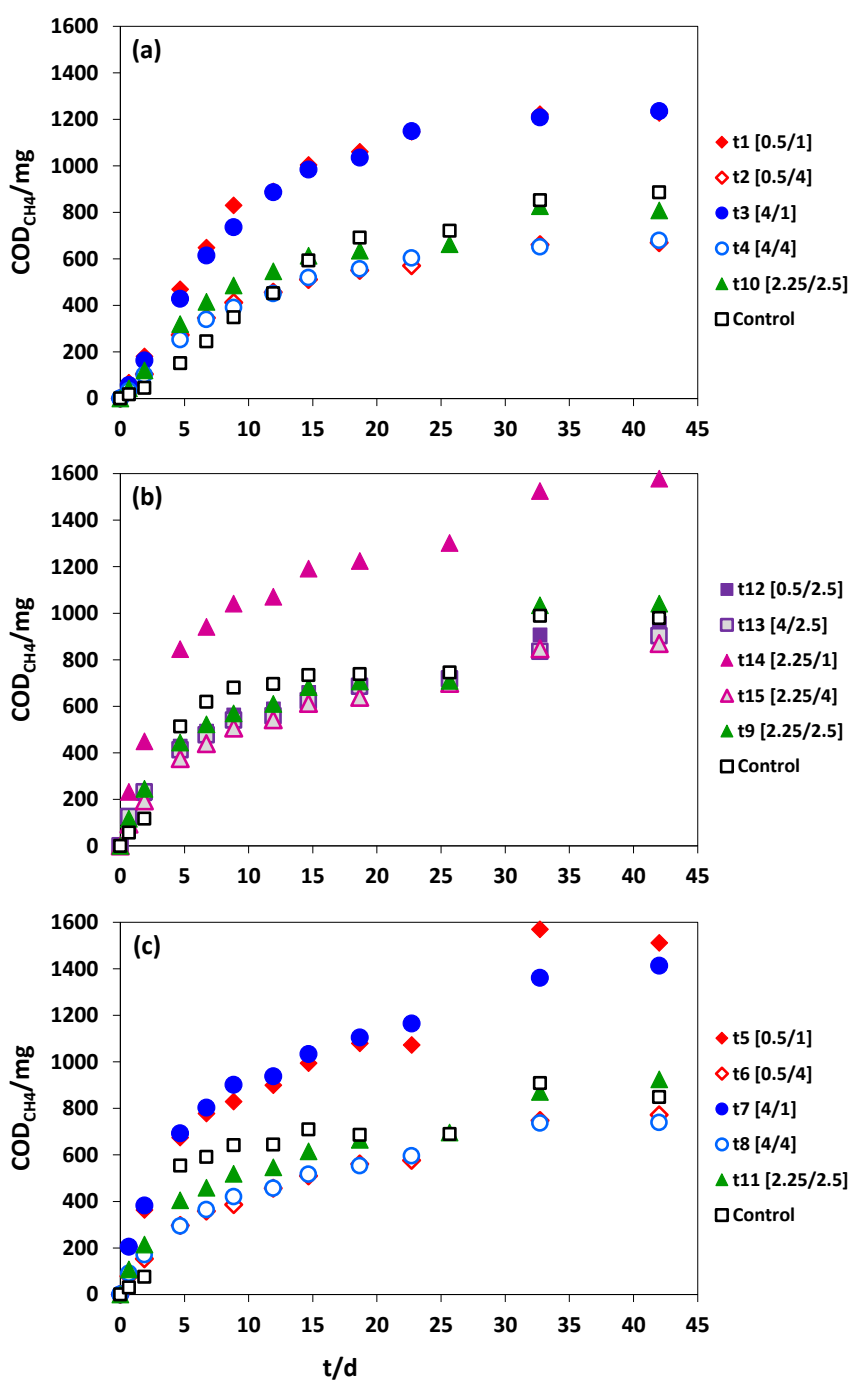

Fig. 1. Cumulative methane production $\left(\mathrm{COD}_{\mathrm{CH} 4}\right)$ with suspended sludge $(\mathbf{a})$, mixed sludge (b) and granular sludge (c) as inoculum. The legend indicates the assay number and respective conditions [particle size $(d p)$ /inoculum to substrate ratio (ISR)] (e.g. t1 $[d p=0.5 \mathrm{~mm} / I S R=1])$.

interactions have more influence on the determination of a BMP for Ulex sp.. The factors with $p$-value $<0.05$ were considered significant (Fig. 2a), i.e. the variables with higher influence in the BMP results were: $\mathrm{A}=\mathrm{C}>\mathrm{B}^{2}>\mathrm{B}>\mathrm{C}^{2}$. Consequently, all the variables should be considered in the model, as defined by Eq. (7), where $A, B$ and $C$ are the actual values of the inoculum type, $d p$ and ISR, respectively. The model $\mathrm{R}^{2}$ and Predicted $\mathrm{R}^{2}$ were 0.945 and 0.927 , respectively. No interactions were considered significant.

$$
\begin{aligned}
B M P= & 126.79+32.58 A+30.74 B+16.84 C-7.88 B^{2} \\
& +4.21 C^{2}
\end{aligned}
$$

The higher variability in the BMP results occurs due to changes in the ISR factor, i.e. decreasing the ISR from $4 \mathrm{~g} \mathrm{~g}^{-1}$ to $1 \mathrm{~g} \mathrm{~g}^{-1}$, caused $35 \%$ to $40 \%$ decrease in the BMP determined for Ulex sp. (Table 3). This trend is clearly visible in the response surface of the $B M P$ results as a function of the Inoculum and ISR for $d p=1.95 \mathrm{~mm}$ (Fig. 3b), and as a function of the $d p$ and ISR for the granular sludge (Fig. 3c). Similar trends were observed for other $d p$ and inoculum type. When designing a BMP assay is necessary to ensure that the inoculum concentration is high enough to prevent inhibition.
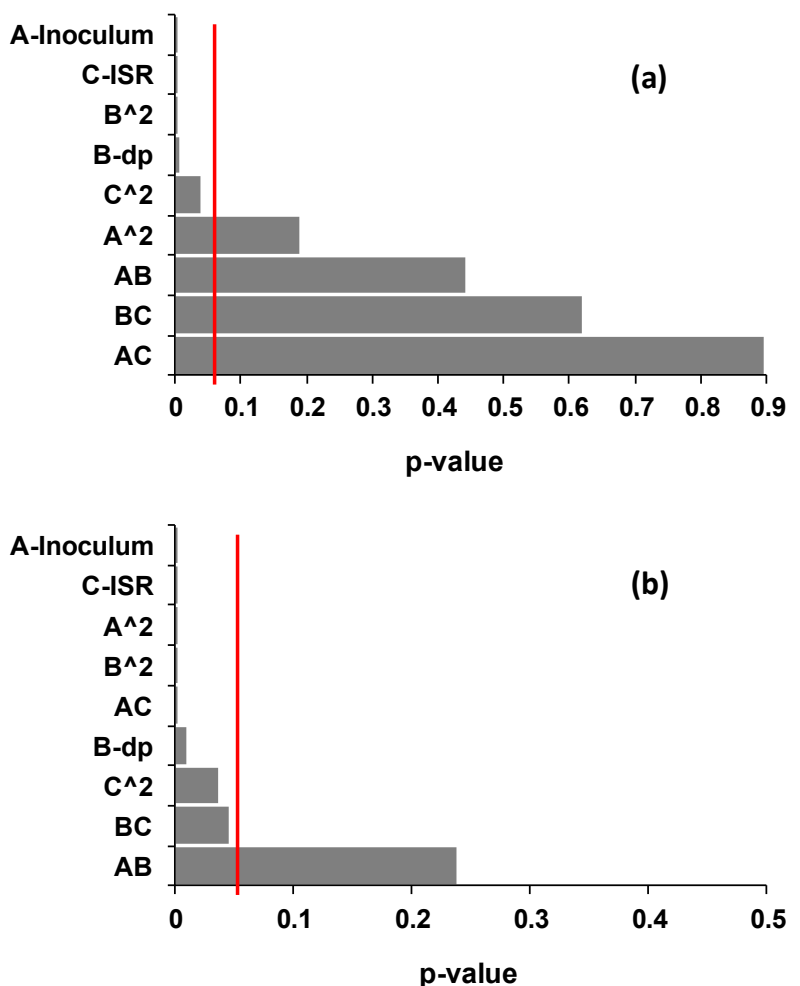

Fig. 2. $p$-value of the linear, quadratic and interaction factors of the CCFC model for the response variables: (a) BMP, and (b) $k$. Values of $p$-value $<0.05$ indicate that the model factors are significant.

Theoretically, the BMP should be independent of the ISR, but in this study the BMP results were influenced by the ISR ratio suggesting that inhibition occurred in the assays with low ISR. Neves et al. [11] used different ISR values when digesting kitchen waste and stated that the ISR was more important than other factors such as activity and alkalinity. Although the optimum ISR was not determined within the range studied, according to our model we can say that at least an $I S R=4 \mathrm{~g} \mathrm{~g}^{-1}$ is necessary.

The $B M P$ is determined as the maximum methane that can be produced by a given substrate, i.e. it is calculated as the maximum plateau of the cumulative methane production profiles. According to these, only the biodegradability rate should depend on the inoculum type, source, activity, concentration, etc., and the BMP should be independent. However the BMP determined with suspended sludge were $12 \%$ to $23 \%$ lower than the BMP of the same assays using granular sludge as inoculum (Table 3, Fig. 3a,b), considering a similar time frame (e.g. in Table 3, assays 1-3 and 13-15 had the same conditions, except the type of inoculum). As observed in the surface plots the BMP increased with higher percentages of granular sludge (Fig. 3a,b), although with lower variation when compared with the ISR effect (Fig. 3b). Although no interactions were considered significant (Fig. 2a), it is possible to state that by using granular sludge as inoculum the ISR can be decreased, while attaining the same BMP (Fig. 3b). Probably this is because granular sludge has a significantly higher specific methanogenic activity. Thus, we propose that the ISR parameter could consider the quality (activity) and not only the quantity (solids) of inoculum. Eventually, by extending the time frame, the BMP differences between each assay would be decreased or even eliminated.

The inoculum type and concentration had high influence in the organic matter solubilisation since the $P_{\text {Sol }}$ varied significantly. Though the granular sludge had higher percentage of solubilisation, 

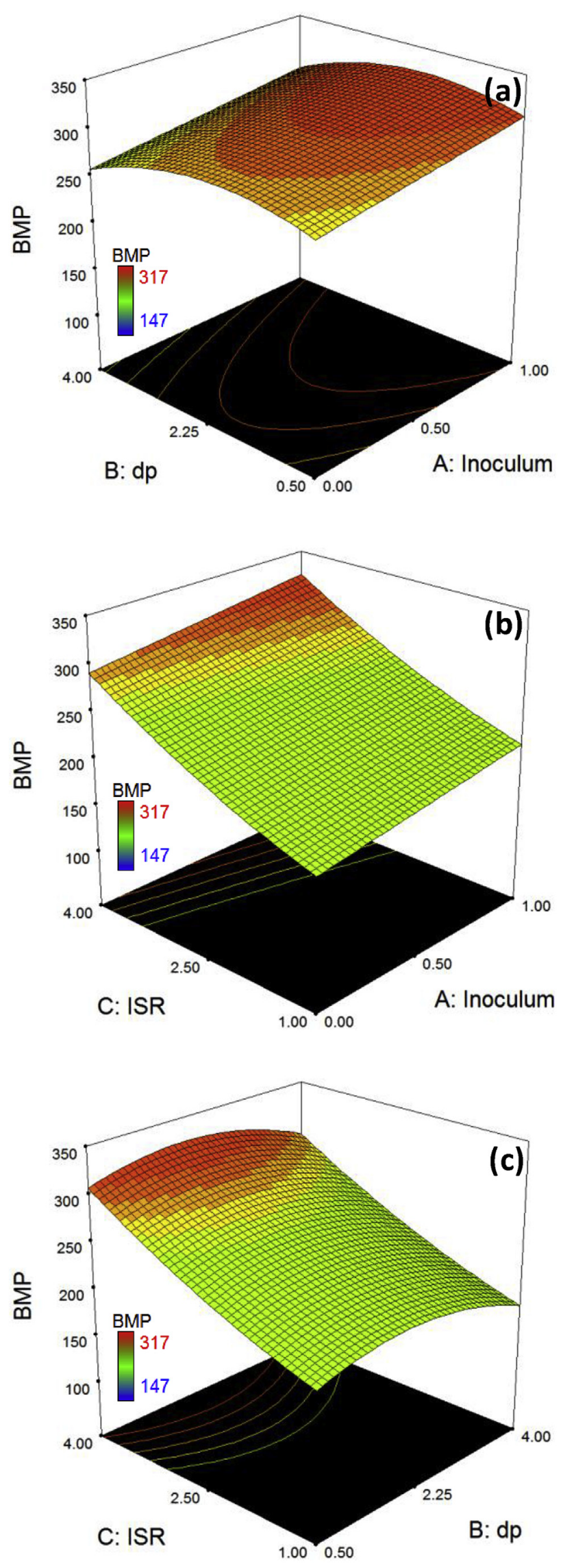

the accumulation of intermediates partially inhibited the methanogenesis, being $17 \%$ of the soluble COD not converted to methane. This value was slightly smaller, around $10 \%$, for the suspended and the mixed sludge. The main problem with Ulex sp. biodegradation was its recalcitrant nature, which made it impossible to achieve higher solubilisation yields. Ulex sp. contains compounds that are poorly or not biodegradable, meaning lignin and glucan, booth consist around one third of the biomass composition. No inhibition by ammonia was observed.

The significant effect of $d p$ and $d p^{2}$ is also visible (Fig. 2a). Indeed, regarding the particle size, a concave surface was observed, with the optimal particle size near the middle level tested. According to the model defined by the statistical analysis, the maximum BMP for Ulex sp. would be obtained using granular sludge as inoculum $\left(\mathrm{X}_{1}=1\right)$, an ISR of $4 \mathrm{~g} \mathrm{~g}^{-1}$ and a $d p$ of $1.95 \mathrm{~mm}$ (upper corner in Fig. $3 \mathrm{~b}$ ). In those conditions the BMP would be $324 \mathrm{~L} \mathrm{~kg}^{-1}$, representing a methane yield of $65 \%$, which is a remarkable value for practical purposes.

\subsection{Biodegradability rate}

The initial biodegradability rate $(k)$ was determined as the slope of the initial specific methane production and is expressed by volume of $\mathrm{CH}_{4}$ per mass of VS of waste and time $\left(\mathrm{L} \mathrm{kg}^{-1} \mathrm{~d}^{-1}\right)$. Ulex sp. show an initial biodegradability rate ranging from 14.1 $\mathrm{L} \mathrm{kg}^{-1} \mathrm{~d}^{-1}$ to $49.2 \mathrm{~L} \mathrm{~kg}^{-1} \mathrm{~d}^{-1}$ (Table 3). Fig. 2b shows the $p$ value for each variable tested and their interactions. The variables with $p$-value $<0.05$ are considered significant, whereas lower values correspond to the most significant parameters. Thus the model should consider: $A=C=\mathrm{A}^{2}=\mathrm{B}^{2}>A C>\mathrm{B}>C^{2}>B C$. The model defined by the Eq. ( 8 ) is significant ( $p$-value $<0.0001$ ), has a $\mathrm{R}^{2}=0.978$ and a Predicted $\mathrm{R}^{2}=0.965$. In Eq. (8), $A, B$ and $C$ represent the actual values of inoculum type, $d p$ and ISR, respectively.

$$
\begin{aligned}
k= & 7.55+36.15 A+4.18 B+5.09 C-1.44 A C-0.25 B C \\
& -27.75 A^{2}-0.89 B^{2}+0.50 C^{2}
\end{aligned}
$$

According to the model defined by Eq. (8), the best initial biodegradability rate $\left(47.2 \mathrm{~L} \mathrm{~kg}^{-1} \mathrm{~d}^{-1}\right)$ would be obtained with a mixture of suspended and granular sludge $(45 / 55 \mathrm{v})$, $d p=1.80 \mathrm{~mm}$ and $I S R=4 \mathrm{~g} \mathrm{~g}^{-1}$. The ISR effect is almost linear, and the biodegradability rate increased with the ISR, as expected (Fig. 4b,c).

The inoculum type factor showed a concave surface (Fig. 3a,b). The optimal biodegradability rate was obtained for $55 \%$ of granular sludge and $45 \%$ of suspended sludge (Fig. 3b). This is an important outcome of this work that demonstrates as the mixing of inocula as a strategy to be considered for a faster methane production rate, from complex substrates. Also, the particle size shows a concave surface with the optimum diameter at $1.80 \mathrm{~mm}$ (Fig. 3a,c).

\subsection{Optimization of the anaerobic biodegradability of Ulex sp. and potential energy generation}

An anaerobic process for the biodegradability of Ulex sp. should consider both the optimization of the specific methane production and the initial biodegradability rate. In this way it is possible exploit the methane recovered from the substrate but also decreases the size and hydraulic retention time of the bioreactor, and

Fig. 3. Response surface of the Biochemical Methane Potential $\left(B M P /\left(\mathrm{L} \mathrm{kg}^{-1}\right)\right)$ of Ulex sp. as a function of: (a) inoculum and $d p\left(I S R=4.0 \mathrm{~g} \mathrm{~g}^{-1}\right)$; (b) Inoculum and ISR $(d p=1.95 \mathrm{~mm}) ;(\mathbf{c}) d p$ and ISR (Inoculum $=100 \%$ granular sludge). 

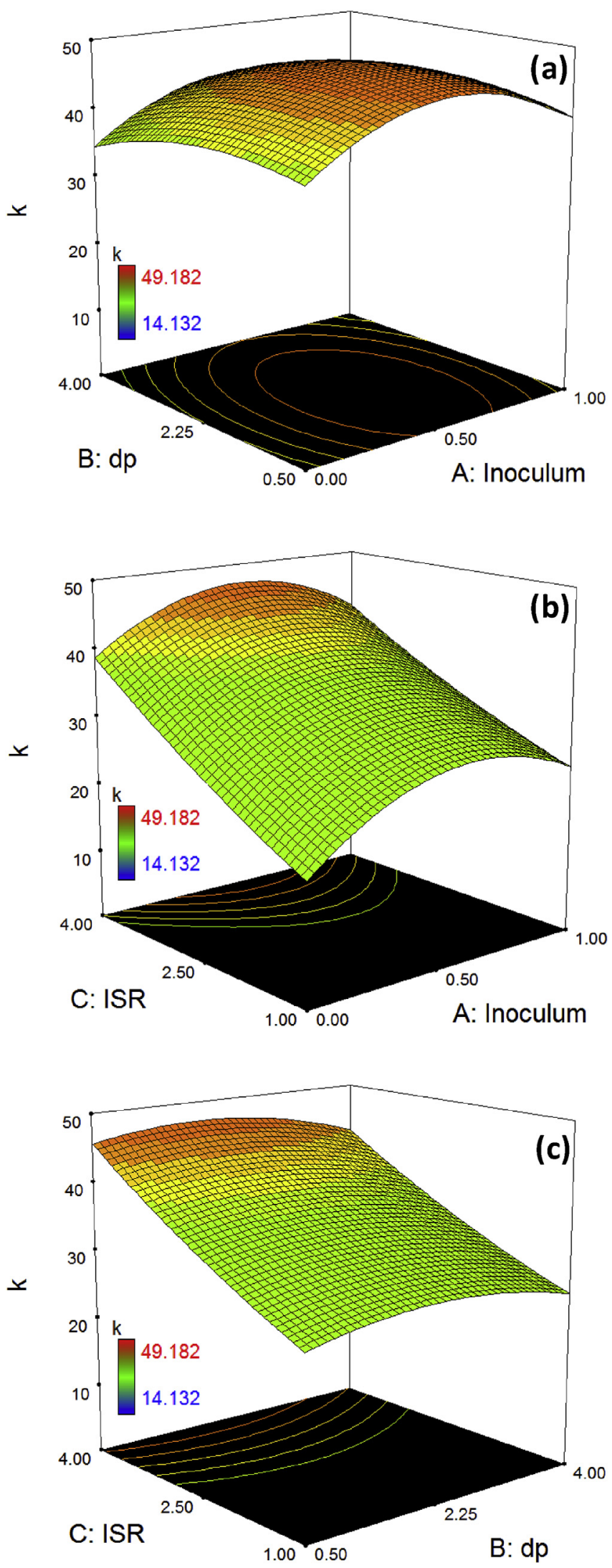

Fig. 4. Response surface of the initial biodegradability rate $\left(k /\left(\mathrm{L} \mathrm{kg}^{-1} \mathrm{~d}^{-1}\right)\right)$ of Ulex sp. as a function of: (a) inoculum and $d p$ (ISR $=4.0 \mathrm{~g} \mathrm{~g}^{-1}$ ); (b) Inoculum and ISR $(d p=1.80 \mathrm{~mm}) ;(\mathbf{c}) d p$ and ISR (Inoculum $=55 \%$ granular sludge $+45 \%$ suspended sludge). consequently decrease the costs associated. According to the models defined, the concomitant optimization of BMP and $k$ suggests the use of an inoculum with $56 \%$ of granular sludge and $44 \%$ of suspended sludge, a particle size of $1.90 \mathrm{~mm}$, and an ISR of $4.0 \mathrm{~g} \mathrm{~g}^{-1}$. At these operational conditions it would be produced $313 \mathrm{~L} \mathrm{~kg}^{-1}$ with and initial biodegradability rate of $46.8 \mathrm{~L} \mathrm{~kg}^{-1} \mathrm{~d}^{-1}$.

Depending on climatic conditions, age when harvested, soil fertility and texture, depth and nature of the bedrock, and $\mathrm{pH}$, the productivity in dry tones of $U$. europaeus varies between $2.3 \mathrm{t} \mathrm{ha}^{-1} \mathrm{yr}^{-1}$ and $7.5 \mathrm{t} \mathrm{ha}^{-1} \mathrm{yr}^{-1}$ [22], giving a potential methane production (STP) of $475 \mathrm{~m}^{3} \mathrm{ha}^{-1} \mathrm{yr}^{-1}$ to $1549 \mathrm{~m}^{3} \mathrm{ha}^{-1} \mathrm{yr}^{-1}$, resulting in an energy value of $(36.9 \pm 19.3) \mathrm{GJ} \mathrm{ha}^{-1} \mathrm{yr}^{-1}$. The total forest area in Europe is 1.1E9 ha [23]. Considering that 20\% of total forest area is shrub and that only $60 \%$ of the total shrub land area can be used for energy exploitation, to keep the ecological maintenance [5], an average estimate energy supply of $(4.6 \pm 2.4) \mathrm{EJ} \mathrm{yr}^{-1}$ could be reached in Europe, which is about $6.5 \%$ of the European energy needs [23].

\section{Conclusions}

- BMP of Ulex sp. varied from $153 \mathrm{~L} \mathrm{~kg}^{-1}$ to $308 \mathrm{~L} \mathrm{~kg}^{-1}$. Higher BMP values were obtained with higher ISR and granular sludge as inoculum.

- $k$ varied between $14 \mathrm{~L} \mathrm{~kg}^{-1} \mathrm{~d}^{-1}$ to $49 \mathrm{~L} \mathrm{~kg}^{-1} \mathrm{~d}^{-1}$. A mixture of granular and suspended sludge and a high ISR had a positive effect on the initial biodegradability rate.

- No inhibitions were observed and the hydrolysis was the limiting step.

- An inoculum consisting in $55 \%$ of granular sludge and $45 \%$ of suspended sludge (v/v), an ISR of at least $4 \mathrm{~g} \mathrm{~g}^{-1}$, and a particle size of $1.85 \mathrm{~mm}$ were defined as the optimal condition to simultaneously maximize the BMP and $k$.

- Considering data of shrub land area in Europe, the energy potential demonstrated from Ulex sp., could result in an average

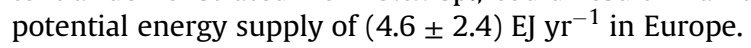

\section{Acknowledgements}

The authors acknowledge the financial support of the Portuguese Science Foundation (FCT) and European Social Fund (ESF, POPH-QREN) through the grant given to José Carlos Costa (SFRH/ $\mathrm{BDP} / 48962 / 2008)$, and through the project FCOMP-01-0124FEDER-027914 (PTDC/AAG-TEC/3048/2012), financed by FEDER through COMPETE - Programa Operacional Factores de Competitividade; and FCT Strategic Project PEst-OE/EQB/LA0023/2013, the FCT Project RECI/BBB-EBI/0179/2012 and the Project "BioEnv - Biotechnology and Bioengineering for a sustainable world", REF. NORTE-07-0124-FEDER-000048, co-funded by the Programa Operacional Regional do Norte (ON.2 - O Novo Norte), QREN, FEDER.

\section{References}

[1] S. Lowe, M. Browne, S. Boudjelas, M. De Poorter, 100 of the World's Worst Invasive Alien Species: a Selection from the Global Invasive Species Database, Published by The Invasive Species Specialist Group (ISSG) a specialist group of the Species Survival Commission (SSC) of the World Conservation Union (IUCN), 2000, p. 12, www.issg.org/booklet.pdf.

[2] B. Hornoy, M. Tarayre, M. Hervé, L. Gigord, A. Atlan, Invasive plants and enemy release: evolution of trait means and trait correlations in Ulex europaeus, PLoS One 6 (10) (2011) e26275. http://dx.doi.org/10.1371/journal.pone.0026275.

[3] M.T. Misset, J.P. Gourret, Flow cytometric analysis of the different ploidy levels observed in the genus Ulex L. Faboideae-Genisteae in Brittany (France), Bot. Acta 109 (1996) 72-79.

[4] AFN, Estatísticas dos incêndios florestais. Totais Nacionais (2001-2010), Autoridade Nacional Florestal. Ministério da Agricultura do Desenvolvimento, Rural e das Pescas, Lisboa, Portugal, 2010. 
[5] L. Núñez-Regueira, J. Proupín-Castiñeiras, J.A. Rodríguez-Añon, Energy evaluation of forest residues originated from shrub species in Galicia, Bioresour. Technol. 91 (2004) 215-221. http://dx.doi.org/10.1016/S0960-8524(03) 00169-X.

[6] D.R. Clements, D.J. Peterson, R. Prasad, The biology of Canadian weeds. 112 Ulex europaeus L. Can. J. Plant Sci. 81 (2001) 325-337.

[7] M. Rees, R.L. Hill, Large-scale disturbances, biological control and the dynamics of gorse populations, J. Appl. Ecol. 38 (2001) 364-377. http://dx.doi. org/10.1046/j.1365-2664.2001.00598.x.

[8] H. Viana, D.J. Vega-Nieva, L. Ortiz Torres, J. Lousada, J. Aranha, Fuel characterization and biomass combustion properties of selected native woody shrub species from central Portugal and NW Spain, Fuel 102 (2012) 737-745. http:// dx.doi.org/10.1016/j.fuel.2012.06.035.

[9] D.P. Chynoweth, J.M. Owens, R. Legrand, Renewable methane from anaerobic digestion of biomass, Renew. Energy 22 (2001) 1-8. http://dx.doi.org/10 1016/S0960-1481(00)00019-7.

[10] M. Eiroa, J.C. Costa, M.M. Alves, C. Kennes, M.C. Veiga, Evaluation of the biomethane potential of solid fish waste, Waste Manage 32 (2012) 1347-1352. http://dx.doi.org/10.1016/j.wasman.2012.03.020.

[11] J. Ariunbaatar, A. Panico, G. Esposito, F. Pirozzi, P.N.L. Lens, Pretreatment methods to enhance anaerobic digestion of organic solid waste, Appl. Energy 123 (2014) 143-156. http://dx.doi.org/10.1016/j.apenergy.2014.02.035.

[12] L. Neves, R. Oliveira, M.M. Alves, Influence of inoculum activity on the biomethanization of a kitchen waste under different waste/inoculum ratios, Process Biochem. 39 (2004) 2019-2024, in: http://dx.doi.org/10.1016/j. procbio.2003.10.002.

[13] A. Mshandete, L. Björnsson, A.K. Kivaisi, M.S.T. Rubindamayugi, B. Mattiasson, Effect of particle size on biogas yield from sisal fibre waste, Renew. Energy 31 (2006) 2385-2392. http://dx.doi.org/10.1016/j.renene.2005.10.015.

[14] J.C. Costa, S.G. Barbosa, M.M. Alves, D.Z. Sousa, Thermochemical pre- and biological co-treatments to improve hydrolysis and methane production from poultry litter, Bioresour. Technol. 111 (2012) 141-147. http://dx.doi.org/10. 1016/j.biortech.2012.02.047.

[15] I. Angelidaki, M.M. Alves, D. Bolzonella, L. Borzacconi, L. Campos, A.J. Guwy, S. Kalyuzhnyi, P. Jenicek, J.B. van Lier, Defining the biomethane potential (BMP) of solid organic wastes and energy crops: a proposed protocol for batch assays, Water Sci. Technol. 59 (2009) 927-934. http://dx.doi.org/10.2166/wst. 2009.040.

[16] APHA, AWWA, WPCF, Standard Methods for the Examination of Water and Wastewater, 17th ed., American Public Health Association, Washington, DC, 1998.

[17] A. Sluiter, B. Hames, R. Ruiz, C. Scarlata, J. Sluiter, D. Templeton, D. Crocker, Determination of Structural Carbohydrates and Lignin in Biomass Laboratory Analytical Procedure, Technical Report NREL/TP-510-42618, Revised June 2010, National Renewable Energy Laboratory, Golden, Colorado, USA, 2008.

[18] J. Wang, W. Wan, Experimental design methods for fermentative hydrogen production: a review, Int. J. Hydrogen Energy 34 (2009) 235-244. http://dx. doi.org/10.1016/j.ijhydene.2008.10.008.

[19] NIST/SEMATECH, 5. Process Improvement, 2012 [Online], http://www.itl.nist. gov/div898/handbook/ (accessed December 2013).

[20] J.C. Costa, M.M. Alves, Posttreatment of olive mill wastewater by immobilized $\mathrm{TiO}_{2}$ photocatalysis, Photochem. Photobiol. 89 (2013) 545-551. http://dx.doi. org/10.1111/php.12023.

[21] A.T.W.M. Hendriks, G. Zeeman, Pre-treatments to enhance the digestibility of lignocellulosic biomass, Bioresour. Technol. 100 (1) (2009) 10-18. http://dx. doi.org/10.1016/j.biortech.2008.05.027.

[22] S. Pérez, C.J. Renedo, A. Ortiz, F. Delgado, I. Fernández, Energy potential of native shrub species in northern Spain, Renew. Energy 62 (2014) 79-83. http://dx.doi.org/10.1016/j.renene.2013.06.048.

[23] European Commission, Eurostat, 2015 [Online], http://ec.europa.eu/eurostat/ (accessed May 2015). 